\title{
Trade Protectionism and Border Closure in Nigeria: The Rice Economy in Perspective
}

\author{
Alex Amaechi Ugwuja and Chimdi Chukwukere \\ http://dx.doi./org/10.4314/ujah.v22i1.4
}

\begin{abstract}
Rice is one of those staples that Nigerians cannot do without; several tonnes of rice are consumed by Nigerians on daily basis. Yet its domestic cultivation and processing are largely ignored by a greater percentage of ordinary Nigerians. Although scholars have produced fascinating studies on both the domestic production of rice, its international trade, and the border closures that are contrived to facilitate local production, there is scarcely any serious scholarly effort that attempts to examine Nigeria's rice economy from the political-economic perspective, especially with attention on the gainers and losers during periods of border closures in Nigeria. This study intervenes in the discourse by focusing on the politicaleconomic implications of Nigeria's rice economy. The major thrust of the research is to discover how far the trade protectionist efforts of the governments of Nigeria impact the domestic economy. In essence, it seeks to discover the gainers and losers of Nigeria's border closures.
\end{abstract}

Keywords: Trade Protectionism, Rice Economy, Political Economy, the Nigerian economy, Border Closure. 


\section{Introduction}

On August 20, 2019, the federal government of Nigeria issued an executive order for the closure of Nigeria's land borders against all imports, especially rice and cars. This directive sparked a rebuttal from not only local consumers of imported rice, but also from neighboring countries -Cameroon, Togo, and the Benin Republic. This ban witnessed an astronomical rise in rice smuggling through the land borders of Nigeria as Asian markets, Thailand, most especially increased rice exports to Nigeria's closest neighbors: Benin from 805,765 tons in 2015 to $1,811,164$ tons and Cameroon from 449,297 tons to 775,175 tons respectively (TREA, 2020). By importing more than their consumption needs, these countries through informal traders smuggled the excesses into the Nigerian markets through her porous borders. As some observers have noted, Nigeria has long had some of the most restrictive import barriers in the world, including very high tariffs and import prohibitions, while Benin (and Togo) have deliberately maintained low import taxes to foster their roles as entrepôts for Nigeria (Igué and Soulé, 1992). Firstly, imports per capita into Benin of certain products that are heavily protected in Nigeria are far too large to be explained by Benin's domestic consumption (Golub et al, 13). Secondly, almost all of Benin's rice imports are of parboiled rice, the preferred type of rice in Nigeria but not in Benin. This provides additional evidence that the large volume of rice imports in Benin is intended primarily for Nigerian markets (Golub et al, 13).

The border closures have had particularly negative consequences for traders, especially informal ones along the BeninNigeria corridor (Mbaye et al, 2019). This is because of the entwined nature of Nigeria-Benin economies (Golub \& Mbaye, 2019). Consequently, on February 10, 2020, the Heads of States of ECOWAS set up a committee headed by President Roch Kabore of 
Burkina Faso to study and make a full report on Nigeria's land border closure with her neighbors, as this violates the ECOWAS and AU protocols. The Nigerian government, on the other hand, averred that the border closure was a positive outcome for the economy as local production of food crops such as rice increased while local consumption of petrol has also reduced. Nigeria vowed to uphold the land border closure until its neighbors, mainly Benin, Niger, and Chad regulated their sides of the borders. Local rice producers expectedly welcomed the development and agreed with the government that the expected results will gradually become noticeable. Drawing from randomized surveys, interviews, and official reports, this study attempts to examine the political economy of Nigeria's trade protectionism, especially as it concerns the rice economy. Our statistical data derive primarily from the Food and Agriculture Organization of the United Nations, Tradingeconomics, Nairametrics, Thai Rice Exporters Association, National Bureau of Statistics (NBS), and the World Development Indicators. The research seeks to find answers to the following questions: What are the political motives for the rice ban? How has it affected NigeriaThai relations?? How does this affect informal traders in neighboring countries like Cameroon and Benin? And importantly, who gains and who loses from this policy? Our questions are thus framed after examining the extant studies on this discourse.

Indeed, profound but staggered literature exists on Nigeria's trade relations, trade policies, border closure, and rice economy. Perspectives are as disparate as there are authors. For example, Akpokodge, Lancon, and Erenstein (2001) examine rice production, consumption patterns, and trade among different regions. The study also considered issues of marketing, processing, and profitability of the rice economy in Nigeria. The authors note that despite several 
government interventions on domestic production, including restriction of import, all seem not to be well with local production. Of significant point is their observation that 'often there is no real analysis of [Nigeria's] trade policies situation'. This point is very relevant. Our present study attempts to fill this lacuna by asking questions and proffering answers on the gainers and losers of Nigeria's incessant border closures. Similarly, Omale, Olorunfemi, and Aiyegbajeje (2020) studied the legal implications of the closure of Nigeria's borders - in 1984, 2003, and 2019. They posit that though the border closures brought some gains to the country, in terms of increased revenues, numerous seizures of illegal materials, and encouragement of local production of rice, they nonetheless assert that in terms of legal, economic, and security implications, Nigeria's border closure is a breach of the fundamental rights of genuine business persons. Their study furnishes a plethora of legal arguments that show the extent to which the state's policies infringe on the rights of citizens. The economic historian may to their legal concerns add the additional question of who gains and who loses during periods of border closures in Nigeria. This angle is one of the major thrusts of the present study. Belesky's (2016) study on rice, politics, and power adds an interesting complexion to the rice economy. He nuances the nexus of economy, politics, and power; detailing how the control of rice cultivation, processing, and marketing, as well as export, has serious political implications in East Asia. Rice is a major stable in Nigeria just as it is in East Asia. The finer point is that the rice economy could be political and Belesky's key summations have parallels with the present study. Many other scholars have studied Nigeria's rice economy from varying prisms. Ogbe, Okoruwa, and Saka (2011) focused on the 
competitiveness of Nigerian rice in terms of production and marketing. Emodi and Madukwe (2008) reviewed policies, acts, and initiatives on rice innovation in Nigeria while Biam and Adejo (2017) sought to discover how rice importation affected local production in the country. Tunji Akande (2013) gives an overview of the Nigerian rice economy while Fakayode, Omotesho, and Omoniwa (2010) presented an economic analysis of rice consumption patterns in Nigeria. What is clear from the above is the fact that studies that attempt a political economy of Nigeria's rice economy, especially with a focus on the gainers and losers do not at present exist. This may well be the most crucial contribution of this present effort.

The study is organized into six sections. From the foregoing introductory part, we reviewed the rice trade policies of the Nigerian government in the second section. The third section places the rice economy in a historical perspective. The fourth section examined the impact of the rice ban and border closure on different actors local rice producers, national economies, consumers, private investors, and multilateral institutions, in essence, the losers and the gainers. The last part contained the recommendations and conclusion.

\section{Review of rice trade policies in Nigeria since 1970}

Since the 1970s, several policies have affected the rice economy in Nigeria. Two factors continue to drive this policy change and they are regime type and the price of oil. According to Obi-egbedi et al (2013), these trade policies can be classified within four policy periods; pre-ban, import quota, ban, and post-ban periods. The first period, which was between 1970 and 1978 featured liberal policies 
on rice imports, and owing to the oil boom of the 1970s, the Nigerian government, overwhelmed by the enormous revenue from oil, abandoned domestic development of the agricultural sector, and instead focused on oil receipts and massive importation of rice and other food items at relatively cheap prices. The government also took charge of the costs of distribution and marketing of this imported rice. Following the global oil crisis and the mounting debtservicing burden during the $1980 \mathrm{~s}$, there was a depletion of the country's foreign reserves, thereby leading to the second trade policy period - the import quota period. According to Obi-egbedi et al (2013), within the period, 1979 -1984, restrictive measures such as the use of import licenses and quotas were used to curb the influx of rice imports into Nigeria. Only a few individuals and government agencies were issued licenses at no tariff charge (Obi-egbedi, 2013).

The third policy period saw an outright ban on rice importation. This was between 1985 and 1995, in addition to the Structural Adjustment Programme (SAP), which was introduced in 1986 to reinforce the ban. Though the SAP by the IMF is usually tied to trade liberalization, its objective in the context of Nigeria's economy was to restructure and diversify the productive base of the economy to reduce dependency on the oil sector and imports. It was also aimed at "achieving a fiscal balance of payments viability over the medium term and promoting non-inflationary economic growth." (NCEMA, 1986). Other measures adopted by the government in this period include exchange rate deregulation and depreciation of the country's currency (naira) (Soludo, 1998). However, illegal rice importation continually thrived, due to the country's porous borders, thus limiting the gains of the protectionist policies. The fourth policy period spanned from 1995 - 2011. This is referred to as the post-ban period. Within this period, as the military regime gave way to democratic regimes, the ban on rice 
importation was lifted as tariffs were set at $100 \%$ and $120 \%$ in 1995 and 2004, respectively. However, Obi-egbedi (2013) states that in 2007, Nigeria assumed a more liberalized policy stance in the wake of the global grain crisis and by 2008, rice imports were allowed into the country at no tariff charge. This was as a result of the government's trade review of 2008 in which the government issued the "2008-2012 Common External Tariff (CET) that harmonizes its tariffs with the Economic Community of West African States (ECOWAS) CET." (USTR). The country's move to a more liberal trade policy was also a step to join the ongoing globalization locomotive driven by the World Trade Organization (WTO) and International Finance Institutions (IFIs). Since 2012, rice tariffs have been raised to $100 \%$ (see table 1 ) from $30 \%$ and $50 \%$ on paddy and milled rice, respectively (USDA, 2012).

Table 1: Nigeria's import barriers on selected products, import tax rates (\%), and import bans, 1995-2018

\begin{tabular}{|l|l|l|l|l|l|}
\hline & $\mathbf{1 9 9 5}$ & $\mathbf{2 0 0 1}$ & $\mathbf{2 0 0 7}$ & $\mathbf{2 0 1 3}$ & $\mathbf{2 0 1 8}$ \\
\hline Beer & $\begin{array}{l}\text { Banne } \\
\mathrm{d}\end{array}$ & 100 & Banned & Banned & $\begin{array}{l}\text { Banne } \\
\mathrm{d}\end{array}$ \\
\hline $\begin{array}{l}\text { Cloth } \\
\text { and } \\
\text { appar } \\
\text { el }\end{array}$ & $\begin{array}{l}\text { Banne } \\
\mathrm{d}\end{array}$ & 55 & Banned & Banned & $\begin{array}{l}\text { rex } \\
\text { ban }\end{array}$ \\
\hline
\end{tabular}




\begin{tabular}{|l|l|l|l|l|l|}
\hline $\begin{array}{l}\text { Poultr } \\
\mathbf{y} \text { meat }\end{array}$ & $\begin{array}{l}\text { Banne } \\
\mathrm{d}\end{array}$ & 75 & Banned & Banned & $\begin{array}{l}\text { Banne } \\
\mathrm{d}\end{array}$ \\
\hline Rice & 100 & 75 & 50 & 100 & 70 \\
\hline Sugar & 10 & 40 & 50 & 60 & 70 \\
\hline $\begin{array}{l}\text { Cigare } \\
\text { ttes }\end{array}$ & 90 & 80 & 50 & 50 & 95 \\
\hline $\begin{array}{l}\text { Used } \\
\text { cars* }\end{array}$ & $\begin{array}{l}\text { Banne } \\
\text { d }\end{array}$ & $\begin{array}{l}\text { Bann } \\
\text { ed }\end{array}$ & Banned & Banned & $\begin{array}{l}\text { Banne } \\
\text { d / 70 }\end{array}$ \\
\hline $\begin{array}{l}\text { Vegeta } \\
\text { ble oil }\end{array}$ & $\begin{array}{l}\text { Banne } \\
\text { d }\end{array}$ & 40 & Banned & Banned & $\begin{array}{l}\text { Banne } \\
\text { d }\end{array}$ \\
\hline
\end{tabular}

Sources: Nigerian customs data provided by the World Bank, Nigerian import prohibition list https://www.customs.gov.ng/ProhibitionList/import.php, online reports, World Trade Organization Nigeria Trade Policy Review 2017. Adopted from Brookings Institute and reworked.

The Nigerian government cited security concerns and the activities of rice smugglers at the borders as her major reason for closing her borders. The government has stated that it will not open the borders until neighboring countries establish border-check mechanisms to curb the activities of smugglers. In November 2019, The Nigerian government through her foreign minister laid out 
conditions that ECOWAS member states must adhere to before her borders would be reopened. These inter alia include that:

...no modification whatsoever to the packaging on those goods imported into an ECOWAS member state destined for Nigeria. So, with the original packaging, they must be escorted from the port directly and transferred to the Nigerian Customs Service. For goods predominantly produced in the ECOWAS member states, the rules of origin must be certified, so we have to avoid any possibilities of dumping. So, if goods are produced in ECOWAS member states, or if they are coming from outside ECOWAS the value addition made by an ECOWAS country must be over $30 \%$. (Onyeama, 2019).

\section{Rice Economy in Nigeria}

In 2017, the demand for imported rice in Nigeria reached 6.7 million tonnes, nearly double the 3.7 million tonnes produced domestically (Akinbile, 2007). Akinbile further notes that Nigeria has a rich history of rice production and consumption, as indigenous rice species (local rice) have been grown in the Niger area for more than 300 years. Over time rice has developed into a major staple crop in the Nigerian diet, with a demand profile cutting across all regions and socioeconomic groups. In retrospect, previous similar initiatives by Nigeria to become self-sufficient in rice production were not very successful. The 1999 Presidential Initiative on Rice and the 2001 National Program for Food Security are recent examples of such initiatives. These initiatives included import barrier policies and other incentives to stimulate local production and achieve selfsufficiency in rice production. Despite this, the initiatives failed to 
achieve their defined goals, as Nigeria continued to remain heavily dependent on rice imports for its consumption needs.

In 2011, the perceived risks of import dependency motivated the Nigerian government to introduce some initiatives under its Agricultural Transformation Agenda (ATA) to address the problems surrounding domestic rice production. The overall goals of the ATA include to re-define agriculture as a business, promote private sector investment in agriculture, encourage the development of private sector-driven marketing organizations, and promote Incentivebased risk-sharing for agricultural lending. According to Adesina (2012), the Federal Government of Nigeria's new policy on agriculture provided fiscal incentives to encourage domestic import substitution and private sector investment in the agricultural sector. These incentives included removal of restrictions on areas of investment and maximum equity ownership in investment by foreign investors; free transfer of capital, profits, and dividends; constitutional guarantees against nationalization/expropriation of investments; zero percent $(0 \%)$ duty on agricultural machinery and equipment imports; a pioneer tax holiday for agricultural investments; and duty waivers and other industry-related incentives (e.g., based on the use of local raw materials, export orientation, etc.).

Furthermore, in August 2014, Dangote Industries Limited signed a Memorandum of Understanding (MoU) with the Federal Government of Nigeria for a US $\$ 1$ billion investment in commercial rice farming and modern integrated rice mills (Okudua, 2017). The Chairman of the Dangote Group, Aliko Dangote, promised that once his company begins to produce rice, the price of the locally produced rice will be cheaper than the price of imported rice and that this will create room for further investments in the sector (Okudua, 2017). Among others, Olam Rice Farms, Stallion Foods, Best Foods, Tara 
Rice, Lumana Rice, Umza Farms, Ebonyi Rice as well as the Dangote Group have committed resources for domestic rice farming and processing and according to the ministry of agriculture, investment in domestic rice processing reached nearly US $\$ 5$ billion (for processing about 4 million metric tons of processed rice per year) in 2014, from an approximate US $\$ 3.5$ billion investment in 2012 (Nzeka, 2014).

Formal imports accounted for a significant proportion of rice consumption in the country. However, the proportion decreased considerably after food prices soared in 2007, shifting from 63 percent in 2006 to 4 percent in 2008, 12 percent in 2009, and 22 percent in 2010 (FAO, 11). Informal trade plays an important role in bridging the gap between local production and domestic demand for cereals, although detailed estimates are not available. Informal cross-border trade of rice is widespread in Nigeria. Tariff protection has encouraged cross-border smuggling. Particularly, paddy rice imported to Benin, also known as "Cotonou Rice", is then reexported to Nigeria where it is transported to deficit areas, particularly urban areas such as Lagos (UNIDO 2011, Hashim 1999). A research study on Benin trade data shows important inconsistencies between official and mirror statistics, particularly for products facing import prohibition and/or high tariffs in Nigeria. Moreover, the same study highlights that the per capita consumption of rice in Benin is consistently higher than it is in Nigeria, particularly when protectionist measures are enforced in Nigeria.

\section{Nigeria's Rice Ban and Border Closure: Of Winners and Losers}

Local rice producers appear to have benefited most from the rice ban and subsequent border closure as they have been tasked with providing an extra 3.5 million more tonnes of rice for domestic consumers. These local rice producers comprise smallholder 
farmers \& commercial producers. Between 2004 and 2018 (as table 2 shows below) rice production increased from 3.2 million tonnes to 6.4 million tonnes, respectively. However, the lack of mechanization and other factors including insecurity of crops and farms led to only about 3.6 million tonnes/ha area being harvested. Local millers who previously had to compete, albeit, unfairly with cheaper rice imports have also been voicing their support for the government policy on border closure. Apart from local producers of the commodity, the Nigerian Customs Service (NCS) is one of the government outfits that greatly benefited from the total land border closure. According to the National Bureau of Statistics, the NCS made a record revenue of US $\$ 2.6$ billion following the border closure in 2019 alone (Nairametrics, 2019). This is huge, especially when compared to the previous average record revenue of $\$ 18.3$ million in 2011.

A significant number of the respondents for this study support the viewpoint that the huge windfall in revenue of the NCS is a major incentive influencing the government towards continued enforcement of closed borders. This is even more plausible given the fact that security has, in the estimates of the government, significantly improved in Northern and Southwestern regions since the border closure policy was enforced. We, therefore, posit that the humongous revenue from closed borders is a great incentive to trade protectionism in Nigeria. Apart from the two winners discussed above, private sector and state government investments in the rice economy have also gained from the rice ban and closed borders. Some of these include Olam Rice Farms, Stallion Foods, Best Foods, Tara Rice, Lumana Rice, Umza Farms, Ebonyi Rice, Anambra Rice, Kebbi Rice, Kano Rice, Imo Rice as well as the Dangote Group. However, the overall positive effect of the expected outcomes of the policy is still embroiled in rhetoric and polemics. 
The price of home-grown rice did not see a significant drop and the quality as well, did not improve across many states of the federation in the period under review.

As there were gainers, so were there also losers. Amongst all the countries that were exporting rice to Nigeria, Thailand was the most hit by the rice ban and the land border closure. Table 2 below shows that before the rice ban in 2014, Nigeria was Thailand's highest rice exporting destination. By 2012 alone, Nigeria imported $1,182,518$ tonnes of rice. This figure was three times that of the Benin republic's import from Thailand which stood at 335,096 tonnes.

\section{Table 2: Export Data from Thailand rice exporting Association,} 2012-2014

\begin{tabular}{|c|c|c|c|c|c|}
\hline NO. & $\begin{array}{l}\text { COUNTR } \\
\text { Y }\end{array}$ & 2012 & 2013 & $\begin{array}{l}\text { 2013(JA } \\
\text { N-DEC) }\end{array}$ & $\begin{array}{l}2014(J A \\
\text { N-DEC) }\end{array}$ \\
\hline & & $\begin{array}{l}\text { QUANT } \\
\text { ITY } \\
\text { (MT) }\end{array}$ & $\begin{array}{l}\text { QUAN } \\
\text { TIY } \\
\text { (MT) }\end{array}$ & $\begin{array}{l}\text { QUAN } \\
\text { TITY } \\
\text { (MT) }\end{array}$ & $\begin{array}{l}\text { QUAN } \\
\text { TITY } \\
\text { (MT) }\end{array}$ \\
\hline & World & $6,734,427$ & $\begin{array}{l}6,611,61 \\
7\end{array}$ & $6,611,617$ & $\begin{array}{l}10,969,33 \\
5\end{array}$ \\
\hline 1 & Nigeria & $1,182,518$ & 175,818 & 175,818 & $1,239,810$ \\
\hline 2 & Benin & 335,096 & 919,041 & 919,041 & $1,112,602$ \\
\hline 3 & China & 176,214 & 327,559 & 327,559 & 734,765 \\
\hline 4 & $\begin{array}{l}\text { Cote } \\
\text { D'lvoire } \\
\end{array}$ & 356,807 & 310,098 & 310,098 & 719,771 \\
\hline 5 & South Africa & 366,745 & 419,373 & 419,373 & 535,645 \\
\hline 6 & Cameroon & 278,436 & 282,992 & 282,992 & 517,526 \\
\hline 7 & U.S.A. & 361,722 & 386,844 & 386,844 & 475,536 \\
\hline 8 & Malaysia & 70,768 & 144,281 & 144,281 & 422,167 \\
\hline
\end{tabular}




\begin{tabular}{|l|l|l|l|l|l|}
\hline 9 & Angola & 153,546 & 231,282 & 231,282 & 379,637 \\
\hline 10 & Mozambique & 202,456 & 215,543 & 215,543 & 376,176 \\
\hline
\end{tabular}

Source: Thailand Rice Exporting Association, 2020

However, from 2013 onwards, the figures showed a huge spike in Benin's rice import from Thailand. This was the same period that the Nigerian government shifted towards import substitution policies on several agricultural products, rice inclusive. Golub et al, (2012) highlighted that imports per capita into Benin of certain products that are heavily protected in Nigeria are far too large to be explained by Benin's domestic consumption. From the year 2016 to 2018, Thailand's rice exporting association data shows that Benin's rice import from Thailand jumped to 1,427,098, 1,814,014, and 1,603,285, respectively. Following the land border closure in Nigeria, Benin Republic's rice imports from Thailand dropped drastically from $1,066,581$ in 2019 to 11,507 thereby accounting for a drop of revenue for Thailand, from $\$ 660 \mathrm{k}$ to $\$ 50 \mathrm{k}$, in rice exports to Benin and proving a hard hit on Benin Republic's economy.

The border closure has also hugely affected informal traders in the Benin Republic and the Benin economy as a whole. In Table 3 below, 2018 Indicators of trade facilitation between Benin and Nigeria shows that Benin republic ranks higher than Nigeria in trade facilitation, 107 and 187, respectively. This is largely due to Benin's efficiency at the ports and borders. For instance, it takes 82 hours for import border compliance between vessels and ports in Benin as against 264 for same at Nigeria. This in addition to low import taxes at borders has over time made Benin a preferable destination to Nigeria. In a Brookings Institute policy report, Goleb \& Mbaye posits that ICBT (Intra cross-boundary trade) generates about $20 \%$ of Benin's GDP. This includes gasoline smuggling which employs 
around 40,000 people, about as much as the size of the public sector in Benin, while direct and indirect jobs from used car smuggling are estimated at around 15,000 and 100,000 people, respectively. They further state that Benin's system of import taxation has revolved around maximizing the income from entrepôt trade, by taxing goods when they enter Benin at a rate well below that in Nigeria or taking advantage of Nigeria's import prohibitions. The country's revenues are hit hard when there are border closures or there is a recession in Nigeria due to lower demand for products being traded there (Goleb, Mbaye \& Golubski, 2019). This is exactly the case as Benin Republic's economy has taken a huge downturn over the last six months in 2019.

\section{Table 3: Indicators of trade facilitation, Benin and Nigeria, 2018}

\begin{tabular}{|l|l|l|l|}
\hline & $\begin{array}{l}\text { Trading } \\
\text { across } \\
\text { borders: } \\
\text { overall rank } \\
\text { (190 } \\
\text { countries) }\end{array}$ & $\begin{array}{l}\text { Time } \\
\text { import } \\
\text { border } \\
\text { compliance } \\
\text { (hours) }\end{array}$ & $\begin{array}{l}\text { Time } \\
\text { import } \\
\text { documentary } \\
\text { compliance } \\
\text { (hours) }\end{array}$ \\
\hline Benin & 107 & 82 & 59 \\
\hline Nigeria & 182 & 264 & 144 \\
\hline
\end{tabular}

Source: World Bank Doing Business Indicators 2018.

Significantly affected too are Nigerian consumers and informal traders in Nigeria. The Central Bank of Nigeria notes that "Total informal trade across the borders over 12 months (June 2013May 2014) stood at N1, 090, 890.58 million. Of this, total exports 
amounted to N435, 278.08 million, representing 39.9 percent while imports accounted for the balance of $\mathrm{N} 655,612.5$ million." (CBN, 2015). Other actors that have been adversely affected by the rice ban and border closure are the consumers and the informal traders in Nigeria. As Munshi (2019) notes,

The greatest impact has been on Nigeria's vast informal sector, which at 65 percent of GDP is the largest in sub-Saharan Africa, and on ordinary Nigerians, more than half of whom live in poverty. Inflation rose in October to 11.6 percent year on year, driven by food prices, which jumped 14.1 percent in the same period to an 18-month high. Food costs account for roughly 60 percent of the average Nigerian's spending and the price of the most important staple, rice, has roughly doubled since the border closed.

From our survey, many respondents expressed general resentment and anger against the rice ban policies and the border closure. Their argument mostly anchors on the fact that the price of local rice was far cheaper when the government allowed rice imports than when the borders were closed. The reason for the hike in local rice is not far-fetched: as imported rice depleted from the market, local rice producers increased price to cover up the cost of high-level production with the low rate of mechanization. Figure 1 below shows that the average price of rice per $\mathrm{kg}$ has moved upwards 174 NGN to 255 NGN from 2012 (when rice trade policies were liberalized) to 2020, respectively. A significant number of those who identified as middle-class voiced their resentment over these policies. Although, most of them simply prefer the imported rice because it is supposedly superior to the locally grown one, mostly because of the sandy nature of the latter. 
Figure 1: Rice Prices in Nigeria (2005 - 2020) - Average price per/kg (Naira)

\section{Rice prices in Nigeria (2005 - 2020)}

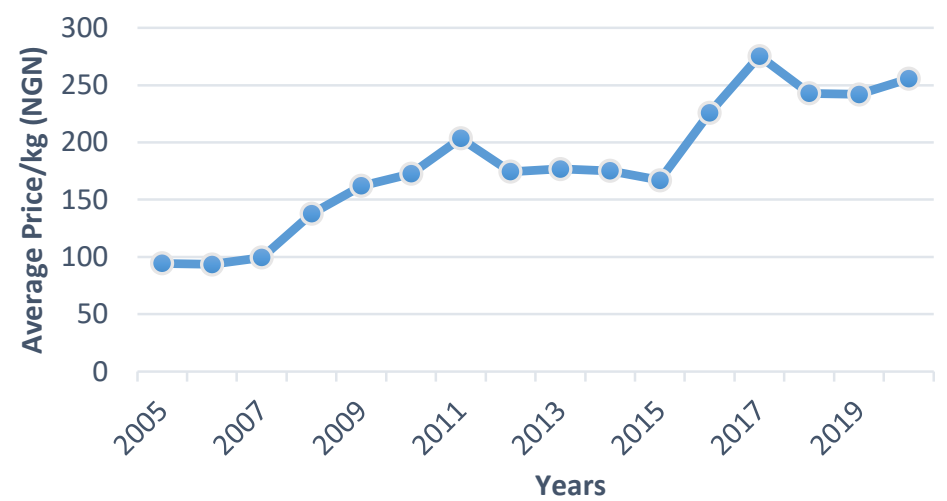

Source: Emedoro (2008) \& FAOSTATS (2020).

Finally, Nigeria's rice policy and the attendant border closure was a slap on the face of a couple of multilateral institutions particularly, ECOWAS, ACFTA, and WTO. The ECOWAS Protocol on Free Movement of People and Goods, which Nigeria is a signatory to, provisions free mobility of the Community's citizens, to wit, citizens of member states. The Protocol on Free Movement confers on the Community's citizens the right to enter and reside in the territory of any member state, provided that they possess a valid travel document and international health certificate. Considering the above, the border closure is contrariwise and injurious to the 
ECOWAS Covenant of which Nigeria is a founding nation. The ECOWAS headquarters is also located in the federal capital territory of Nigeria, Abuja. It was in response to these that a two-day highlevel meeting was held on February 13, 2020, in Ouagadougou, Burkina Faso to assess the situation of the closure of the land borders of Nigeria to goods, and to pursue the overall objective of reaching an acceptable solution to all parties, and propose actions for the rapid reopening of the land borders of Nigeria for the free movement of goods. The border closure had severed Nigeria's trade with Benin, Cameroon, and Niger.

The African Continental Free Trade Area (ACFTA) which Nigeria consented to in July 2019 in a comity of 53 other African countries is a pan-African agreement to establish a free trade zone in the continent. This trade deal promises a reduction of tariffs on goods traded within the bloc. As Devonshire-Elis (2019) posited, "removing tariffs on intra-African trade will boost net income at the continental level by 2.8 billion dollars per annum." However, the fact that the Nigerian government went ahead in August 2019 to introduce the border closure policy raised fears among governments, co-partners, investors, and individuals over her willingness to commit to the African continental free trade agreement. As the government did not rectify this before the agreement came into force in June 2020, ACFTA may be headed nowhere. Also, it should be pointed out that Nigeria's border closure is a violation of her commitment to the world Trade Organization. Article XXII of WTO agreement states that "Each contracting party shall accord sympathetic consideration to, and shall afford adequate opportunity for consultation regarding, such representations as may be made by another contracting party concerning any matter affecting the operation of this agreement." The Nigerian government by her actions seem not to care about other member's interest and this could 
be a case to be filed by any of the neighboring countries. This conduces to ambivalence for a country that had since independence has spent huge resources to construct an external image of an altruistic nation-state (Ugwuja, 2016).

\section{Recommendations and Conclusion}

The study has examined the political economy of the rice ban in Buharis' second coming as well as the attendant border closure. It has also attempted to review the gains and losses of the policy as well as the actors that have gained and those that lost. It concludes by stating that despite tremendous pressure domestically and internationally, the Nigerian government has extended the land border closure against all trade and she continues to emphasize how beneficial this policy has been of benefit to the nation's economy. However, as noted above, not all stakeholders have benefited from this. Some local businesses and major supermarkets such as Shoprite and Spurs have been struggling with stocking chicken among other products. There have also been food inflation and many are starting to doubt whether the African Continental Free Trade Area deal recently signed by 54 African countries, Nigeria inclusive, could be effectively implemented having seen actions like this from the biggest economy in Africa. It should be noted that the land border closure has proved effective for the growth of Nigeria's rice economy. However, the Nigerian government, the Nigerian customs service, and other stakeholders must be proactive in implementing a sustainable solution to resolve this debacle. Following our observations, we recommend that first, the government must understand that closing all trading activities through the land borders is not sustainable. We voluntarily accented to several regional, continental, and even global trade regimes and this requires our compliance if we the country is to avoid retaliation of any form and 
maintain her reputation in international trade relations. It is in the light of this that we urge the federal government of Nigeria to introduce and enforce national and even regional institutional mechanisms that provide for effective verification, certification, and monitoring of the rules or agreements in line with ECOWAS and ACFTA agreements. Also, the Nigerian government must increase its war on corruption, custom officials or government officials who aid informal trade through the land borders be prosecuted fully.

\author{
Alex Amaechi Ugwuja, PhD \\ Department of History and International Studies \\ Nnamdi Azikiwe University, Awka \\ aa.ugwuja@unizik.edu.ng
}

Chimdi Chukwukere

Seton Hall University,

South Orange New Jersey

chukwuch@shu.edu 


\section{Appendix: Supplementary Data on Nigeria's rice economy}

A. Figure 1 - Paddy rice area harvested and the sum of production, 2004-2018.

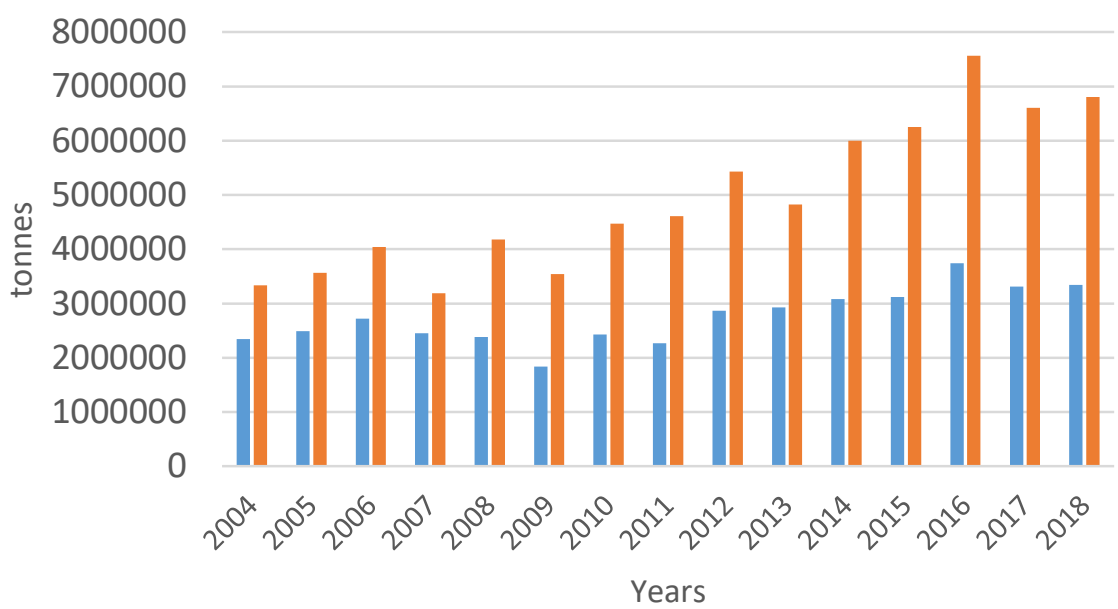

Max of Are

B. Share of Total Production \& Average yield/ha per Production ecology. 


\begin{tabular}{|c|c|c|c|}
\hline $\begin{array}{l}\text { Production } \\
\text { Ecology }\end{array}$ & $\begin{array}{l}\text { The Major } \\
\text { States } \\
\text { covered }\end{array}$ & $\begin{array}{l}\text { Share of total } \\
\text { domestic } \\
\text { production }\end{array}$ & $\begin{array}{l}\text { Average } \\
\text { yield/ha in a } \\
\text { tonne }\end{array}$ \\
\hline $\begin{array}{l}\text { Rain-fed } \\
\text { upland }\end{array}$ & $\begin{array}{l}\text { Ogun, Ondo, } \\
\text { Osun, Ekiti, } \\
\text { Oyo, Edo, } \\
\text { Abuja, } \\
\text { Kwara, Delta, } \\
\text { Sokoto, } \\
\text { Benue, } \\
\text { kaduna \& } \\
\text { Kebbi }\end{array}$ & $17 \%$ & 2.7 \\
\hline $\begin{array}{l}\text { Rain-fed } \\
\text { lowland }\end{array}$ & $\begin{array}{l}\text { Adamawa, } \\
\text { Ondo, Ekiti, } \\
\text { Ebonyi, } \\
\text { Rivers, Cross } \\
\text { River, Akwa } \\
\text { Ibom, Lagos } \\
\text { State. }\end{array}$ & $53 \%$ & 3.2 \\
\hline Irrigated & $\begin{array}{l}\text { Anambra, } \\
\text { Borno, } \\
\text { Adamawa, } \\
\text { Kano, Lagos, } \\
\text { Ogun, Cross } \\
\text { River, Benue, } \\
\text { Sokoto, } \\
\text { Niger, Kebbi, } \\
\text { Enugu. }\end{array}$ & $26 \%$ & 4.4 \\
\hline $\begin{array}{l}\text { Deepwater } \\
\text { floating }\end{array}$ & $\begin{array}{l}\text { Flooded areas } \\
\text { - Rima valley } \\
\text { in Kebbi state }\end{array}$ & $3 \%$ & 1.5 \\
\hline
\end{tabular}




\begin{tabular}{|l|l|l|l|}
\hline & $\begin{array}{l}\text { and deeply } \\
\text { flooded areas } \\
\text { in Kebbi } \\
\text { State. }\end{array}$ & \\
\hline $\begin{array}{l}\text { Mangrove } \\
\text { swamp }\end{array}$ & $\begin{array}{l}\text { Ondo, Delta, } 1 \% \\
\text { Rivers, } \\
\text { Bayelsa, } \\
\text { Cross River } \\
\text { \& Akwa } \\
\text { Ibom }\end{array}$ & \\
\end{tabular}

Source: Emedoro (2008) \& FAOSTATS (2020).

c. Tariff levels on Imported Staple foods in Nigeria.

\begin{tabular}{|c|c|c|c|c|c|c|c|}
\hline $\mathbf{N}$ & COUNTRY & 2016 & & & & & \\
\hline & & QUANTIT & VALUE & QUANTIT & VALUE & QUA & VALU \\
\hline & & (MT) & (MILLIO & (MT) & \begin{tabular}{|l} 
(MILLI \\
T) \\
\end{tabular} & (MT) & $\begin{array}{l}\text { (MILL } \\
\text { IT) }\end{array}$ \\
\hline & WORLD & $\mathbf{9 , 9 0 7 , 8 6 8}$ & 154,733 & $11,674,331$ & 175,161 & 11,088 & 180,27 \\
\hline 1 & BENIN & $1,427,098$ & 18,176 & $1,814,014$ & 23,150 & 1,603, & 20,222 \\
\hline 2 & PHILIPPINES & 308,726 & 3,818 & 291,723 & 3,688 & 1,029 & 13,211 \\
\hline 3 & CHINA & $1,034,10$ & 16,825 & $1,204,91$ & 19,422 & 1,003 & 17,69 \\
\hline 4 & INDONESI & 400,010 & 5,753 & 128,908 & 2,021 & 812,8 & 11,70 \\
\hline 5 & SOUTH & 575,755 & 8,218 & 775,197 & 10,503 & 769,2 & 10,39 \\
\hline
\end{tabular}




\begin{tabular}{|c|c|c|c|c|c|c|c|}
\hline $\begin{array}{l}\mathbf{N} \\
\mathbf{O} .\end{array}$ & $\begin{array}{l}\text { COUNTR } \\
\text { Y }\end{array}$ & 2019 & & $\begin{array}{l}2019 \\
\text { (JAN } \\
\text { FEB) }\end{array}$ & & $\begin{array}{l}2020 \\
\text { (JAN- } \\
\text { FEB) }\end{array}$ & \\
\hline & & $\begin{array}{l}\text { QUANTI } \\
\text { Y (MT) }\end{array}$ & $\begin{array}{l}\text { VALUE } \\
\text { (MILLIO } \\
\text { N BAHT) }\end{array}$ & $\begin{array}{l}\text { QUAN } \\
\text { TIY } \\
\text { (MT) }\end{array}$ & $\begin{array}{l}\text { VALU } \\
\text { E } \\
\text { (MIL } \\
\text { LION } \\
\text { BAHT } \\
\text { ) }\end{array}$ & $\begin{array}{l}\text { QUAN } \\
\text { TIY } \\
\text { (MT) }\end{array}$ & $\begin{array}{l}\text { VALU } \\
\text { E } \\
\text { (MILLI } \\
\text { ON } \\
\text { BAHT) }\end{array}$ \\
\hline & WORLD & $7,580,512$ & 130,544 & $\begin{array}{l}1,639,3 \\
23\end{array}$ & 26,981 & $\begin{array}{l}947,29 \\
4 \\
\end{array}$ & 17,535 \\
\hline 1 & U.S.A. & 559,957 & 19,269 & 97,764 & 3,392 & 93,737 & 3,026 \\
\hline 2 & $\begin{array}{l}\text { SOUTH } \\
\text { AFRICA } \\
\end{array}$ & 725,461 & 9,168 & 115,936 & 1,491 & 86,975 & 1,105 \\
\hline 3 & ANGOLA & 376,492 & 5,002 & 69,472 & 930 & 65,736 & 867 \\
\hline 4 & JAPAN & 266,601 & 3,456 & 45,544 & 624 & 58,725 & 745 \\
\hline 5 & CHINA & 471,339 & 9,336 & 87,922 & 1,579 & 41,825 & 922 \\
\hline 6 & $\begin{array}{l}\text { CAMERO } \\
\text { ON }\end{array}$ & 532,083 & 6,708 & 79,949 & 1,008 & 37,152 & 471 \\
\hline 7 & TOGO & 111,983 & 1,631 & 22,189 & 308 & 36,399 & 474 \\
\hline 8 & $\begin{array}{l}\text { HONG } \\
\text { KONG }\end{array}$ & 169,848 & 5,876 & 29,487 & 1,044 & 35,381 & 1,212 \\
\hline 10 & $\begin{array}{l}\text { MOZAMB } \\
\text { IQUE }\end{array}$ & 272,964 & 3,507 & 59,250 & 767 & 29,611 & 376 \\
\hline 11 & YEMEN & 185,503 & 2,320 & 22,823 & 296 & 26,233 & 319 \\
\hline 13 & KENYA & 176,714 & 2,315 & 54,484 & 725 & 24,342 & 335 \\
\hline 14 & $\begin{array}{l}\text { MALAYSI } \\
\text { A }\end{array}$ & 292,963 & 3,638 & 86,593 & 1,071 & 23,819 & 299 \\
\hline 16 & $\begin{array}{l}\text { COTE } \\
\text { D'LVOIR } \\
\text { E } \\
\end{array}$ & 106,829 & 1,933 & 45,997 & 752 & 22,657 & 342 \\
\hline 22 & BENIN & $1,066,581$ & 13,000 & 226,658 & 2,826 & 11,507 & 164 \\
\hline
\end{tabular}




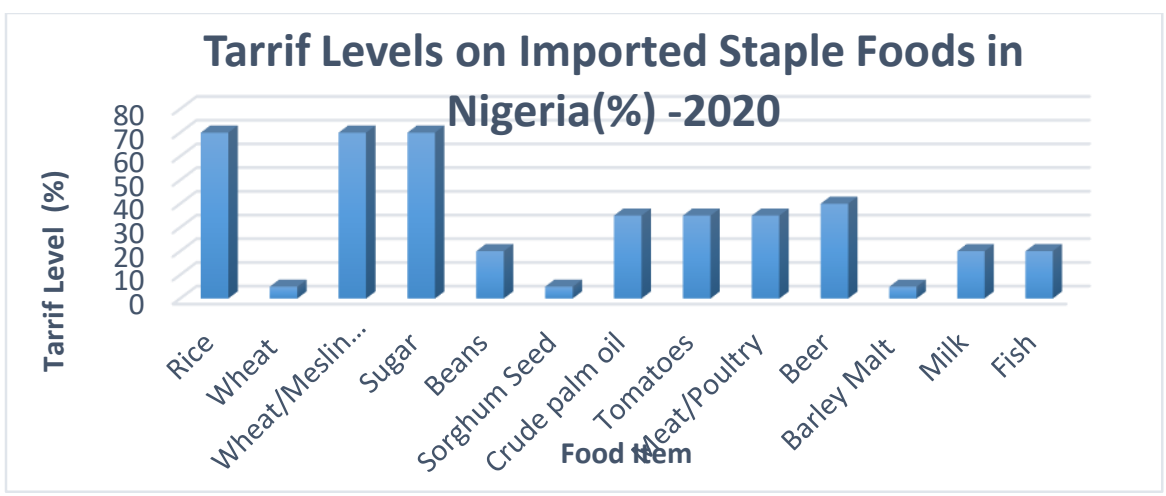

C. Export Data from Thailand rice exporting association, 2016-2018. 


\section{References}

Adesina, A., (2012). "Agricultural Transformation Agenda: Repositioning Agriculture to Drive Nigeria's Economy". Federal Ministry of Agriculture and Rural Development. 18

Agricultural Transformation agenda policy document. (2014). https://reliefweb.int/sites/reliefweb.int/files/resources/nssp wp26.pdf

Akinbile, L. A. (2007). "Determinants of Productivity Level among Rice Farmers in Ogun State, Nigeria." by K. Z. Ahmed, M. A. Mahamoud, S. I. Shalabi, E. A. El-Morsi, and H. A. M. Ismael, (eds) Eighth African Crop Science Conference Proceedings. El-Minia, Egypt: African Crop Science Society.

Akpokodje, G., Lançon, F., and Erenstein, O. (2000). The Nigerian rice economy in a 11competitive world: constraints, opportunities and strategic choices (Bouake, Côte d'Ivoire: West Africa Rice Development Association/USAID).

Belesky, P., (2016). "Rice, politics, and power: the political economy of food insecurity in East Asia". Unpublished Ph.D. Thesis: The University of Queensland, Australia.

Biam, C.K. and Adejo, S.A, (2017). "Rice importation trend in Nigeria and its effects on local production: 1970-2013". Conference Proceedings of the 18" Annual National Conference of The Nigerian Association Of Agricultural 
Economists Held At Federal University o/Agriculture, Abeokuta, Nigeria 16" - 19th October 2017.

Biyi, D. (2005). "Government policies and competitiveness of Nigerian rice economy". Workshop on rice policy \& food security in sub-Saharan Africa. The Federal University of Technology, Akure, Nigeria. 4.

Emodi, I. A, and Madukwe M.C., (2008). "Review of policies, acts, and initiatives in rice innovation system in Nigeria". Journal of Agricultural Extension, 12 (2).

Fakayode, S. B., Omotesho, O. A., and Omoniwa, A. E. (2010). "Economic analysis of rice consumption patterns in Nigeria". Journal of Agricultural Science and Technology, 12.

Golub, S., (2012). 'Entrepôt Trade and Smuggling in West Africa: Benin, Togo, and Nigeria', The World Economy, 35 (9).

Golub, S., Mbaye, A.A, Golubski, C. (2019). The effects of Nigeria's closed borders on informal trade with Benin. Brookings policy report, African in focus. 13

Golub, S., Mbaye, AA, Chiehk, A.D., (2019). Benin Informal Trading with Nigeria. Economic Development \& Institutions. LARES.

Igué, J.O., and Soulé, B., (1992). L'Etat Entrepôt au Benin: commerce informel ou solution a la crise? Editions Karthala, Paris. 4 
Munshi, N. (2019). "Nigerian border closures cut smuggling but drive up prices". Financial Times. Nov. 24.

National Centre for Economic Management \& Administration (NCEMA). (1986). Structural Adjustment Program in Nigeria: Causes, Processes, and Outcomes. NCEMA, Abuja.

Obi-Egbedi O., Okoruwa, V. O., Yusuf, A, Kemisola Adenegan O. and Alarudeen, A (2013). Rice trade Protectionism Versus Liberalization in Nigeria: A CGE Analysis of Economic and Welfare Effects. Africa Association of Agricultural Economists.

Ogbe, O. A., Okoruwa, O.V., and Saka J.O., (2011).

"Competitiveness of Nigerian rice and maize production ecologies: a policy analysis approach". Tropical and Subtropical Agroecosystems, 14, (2).

Okudua, V. (2018). "Assessing the impact of rice sector policy reforms on the income mobility of rural household in Nigeria". The Open Agricultural Journal. DOI: 10.2174/1874331501812010174, 12.

Omale, M.G., Olorunfemi, J.F., and Aiyegbajeje, F.O. (2020). "Legal viable options to incessant closure of Nigeria's international borders", African Identities, DOI: 10.1080/14725843.2020.1828037

PWC policy publication (2018). Boosting Rice production through increased mechanization. www.pwc.com/ng 
Thai Rice Exporting Agency database. https:thairiceexporters.org WTO trade review on Nigeria. (2017). https://www.wto.org/english/tratop_e/tpr_e/s356_sum_e.p $\underline{\mathrm{df}}$

Ugwuja, A.A., (2016), "Shades of African values and interests in Nigeria's international relations: investigating the gains and the costs, 1960-2014", Ogirisi: a Journal of African Studies, (12). 